\title{
Aplikasi Pelayanan Jasa Laundry Berbasis WEB (Studi Kasus : Pelangi Laundry Kisaran)
}

\author{
Muhammad Yasin Simargolang ${ }^{1}$, Nurmala Nasution ${ }^{2}$ \\ ${ }^{1,2,3}$ Program Studi Teknik Informatika, Fakultas Teknik Universitas Asahan \\ Jl Jend.Ahmad Yani, Kisaran, Sumatera Utara 21216, Indonesia \\ ${ }^{1}$ muhammadyasinsegmail.com, ${ }^{2}$ nurmalanstegmail.com
}

\begin{abstract}
Abstrak - Perkembangan dunia di era millennium ini sangat pesat, terutama di bidang teknologi informasi. Tingkat kecepatan dan ketepatan informasi merupakan hal yang sangat besar oleh karena itu harus didukung teknologi informasi yang memadai. Demikian hal nya pada jasa usaha laundry, Pelangi Laundry merupakan sebuah usaha yang menjalankan bisnis dalam bidang jasa laundry. Berdasarkan survey yang telah dilakukan sampai saat ini pelangi Laundry belum memiliki sistem informasi sendiri dan masih menggunakan sistem manual, laundry ini juga belum mempunyai sistem penyimpanan database yang akurat sehingga semua data masih disimpan kedalam sebuah buku. Para pelanggan juga tidak mendapatkan informasi yang up-to-date tentang berbagai jasa laundry yang ditawarkan dan ada juga pelanggan yang merasa kerepotan pada saat mengantar bahkan mengambil laundry yang telah selesai dikarenakan tidak memiliki banyak waktu untuk pergi ke laundry dengan alasan kesibukan. Untuk mengatasi permasalahan tersebut maka akan dirancang suatu aplikasi yang dapat membantu bisnis Pelangi Laundry sehingga aplikasi ini dapat memberikan informasi yang up-to-date dari Pelangi Laundry tentang jasa laundry yang ditawarkan kepada pelanggan, memberikan pelayanan antar jemput laundry yang cepat dan terpercaya kepada pelanggan, memudahkan proses pembuatan laporan pendapatan dengan cepat, tepat dan akurat, memberikan pelayanan yang profesional kepada pelanggan dan meminimalisir kesalahan-kesalahan yang mungkin terjadi.
\end{abstract}

Kata Kunci - Aplikasi, Pelayanan, Laundry

\section{PENDAHULUAN}

Usaha laundry merupakan sebuah bisnis yang berkaitan dengan pelayanan jasa pencucian pakaian dengan mesin cuci maupun mesin pengering otomatis dan cairan pembersih serta pewangi khusus. Bisnis ini menjamur di kota-kota besar yang banyak terdapat rumah kost dan rumah kontrakan, dimana penyewa kost atau kontrakan tidak sempat atau tidak bisa melakukan cuci dan setrika baju sendiri dikarenakan kesibukan sebagai mahasiswa maupun pekerja. Pelangi Laundry salah satu laundry kiloan yang berada di Kisaran. Letaknya yang strategis tepatnya di jln.Latsitarda No.4 Kisaran Timur, membuat banyak pelanggan yang berkunjung setiap hari untuk menggunakan jasa Pelangi Laundry. Namun dibalik kemajuan teknologi informasi yang kini telah berkembang secara pesat, Sampai saat ini pelangi laundry belum memiliki sistem informasi sendiri dan masih menggunakan sistem manual, laundry ini juga belum mempunyai system penyimpanan database yang akurat sehingga semua data masih disimpan ke dalam sebuah buku. Dengan penggunaan sistem yang manual ini timbullah berbagai permasalahan seperti sulitnya mencari data-data pelanggan dalam sebuah buku, pembuatan laporan yang rumit karena harus dibuat dengan merekap data-data yang ada pada buku transaksi, proses transaksi yang lama karena transaksi harus dihitung secara manual, dan pegawai juga kesulitan dalam mencari data ditumpukan buku ketika pelanggan akan mengambil laundry. Bahkan Pelanggan juga tidak mendapatkan informasi yang upto-date tentang berbagai jasa laundry yang ditawarkan dan ada juga pelanggan yang kerepotan pada saat mengantar bahkan mengambil laundry yang telah selesai dikarenakan tidak memiliki banyak waktu untuk pergi ke laundry dengan alasan kesibukan.

\section{LANDASAN TEORI}

A. Aplikasi

Menurut Hasan Abdurahman dan Asep Ririh Riswaya (2014) Aplikasi adalah program siap pakai yang dapat digunakan untuk menjalankan perintahperintah dari pengguna aplikasi tersebut dengan tujuan mendapatkan hasil yang lebih akurat sesuai dengan tujuan pembuatan aplikasi tersebut, aplikasi mempunyai arti yaitu pemecahan masalah yang menggunakan salah satu teknik pemrosesan data aplikasi yang biasanya berpacu pada sebuah komputansi yang diinginkan atau diharapkan maupun pemrosesan data yang diharapkan.Pengertian aplikasi secara umum adalah alat terapan yang difungsikan secara khusus dan terpadu sesuai kemampuan yang dimilikinya, aplikasi merupakan suatu perangkat komputer yang siap pakai bagi user.

Dari pendapat diatas, dapat disimpulkan bahwa Aplikasi adalah suatu program berbentuk perangkat lunak yang berjalan pada suatu sistem tertentu yang berguna untuk membantu berbagai kegiatan yang dilakukan oleh manusia.

\section{B. Sistem Informasi}

Sistem adalah kumpulan dari komponenkomponen yang memiliki unsur keterkaitan antara satu dan lainnya. informasi adalah data yang diolah menjadi bentuk yang lebih berguna dan lebih berarti bagi penerimanya.

Menurut Dani Eko Hendrianto (2014) Sistem Informasi adalah suatu sistem didalam suatu organisasi yang mempertemukan kebutuhan pengolahan data transaksi harian, mendukung operasi, bersifat manajerial, dan kegiatan strategi dari suatu organisasi serta menyediakan pihak luar tertentu dengan laporanlaporan yang diperlukan. 


\section{Layanan Jasa}

Menurut Muhammad Syawal Ainul Yaqin (2016) Layanan berarti membantu menyiapkan atau mengurus apa-apa yang diperlukan seseorang.

Menurut Kotler pelayanan adalah pemberian jasa kepada pelanggan sesuai dengan kebutuhannya. Dikatakan pula bahwa jasa dapat didefinisikan sebagai kegiatan atau manfaat yang dapat diberikan oleh satu pihak kepada pihak lainnya yang pada dasarnya tidak berwujud dan tidak pula berakibat pemilikan sesuatu dan produksinya dapat atau tidak dapat dikaitkan dengan suatu produk fisik.

\section{Laundry}

Menurut Muhammad Syawal Ainul Yaqin (2016) Laundry ialah sebuah departemen housekeeping yang bertugas dan bertanggung jawab untuk memproses semua aktivitas pencucian baik untuk operasional hotel dan tamu hotel.

Laundry adalah kata benda yang mengacu pada tindakan mencuci pakaian, tempat dimana mencuci dilakukan. Laundry juga diartikan sebagai kegiatan mencuci pakaian atau bahan tekstil lainnya dan juga sebagai sebuah tempat untuk mencuci pakaian atau bahan tekstil lainnya.

\section{E. Internet}

Menurut Dani Eko Hendrianto (2014) Internet adalah singkatan dari Interconnected Network. Internet merupakan sebuah sistem komunikasi yang mampu menghubungkan jaringan-jaringan komputer diseluruh dunia.

\section{F. PHP}

Menurut Bunafit Nugroho (2013:153), PHP (kepanjangan PHP Hypertext Preprocessor) itu bahasa pemrograman berbasis web. Jadi PHP adalah bahasa program yang digunakan untuk membuat aplikasi berbasis web (website, blog, atau aplikasi web). PHP termasuk bahasa program yang hanya bisa berjalan di sisi server, atau sering disebut Side Server Language. Jadi program yang dibuat dengan kode PHP tidak bisa berjalan kecuali dia dijalankan pada server web, tanpa adanya server web yang terus berjalan dia tidak akan bisa dijalankan. Sedangkan menurut Refika Khoirunnissa, dkk (2016) PHP adalah bahasa skrip yang kuat yang dirancang untuk memungkinkan pengembang untuk membuat aplikasi web yang sangat cepat dan fitur MySQL adalah yang cepat, basis data handal yang terintegrasi dengan baik dengan PHP dan cocok untuk aplikasi berbasis internet yang dinamis

\section{G. $\quad M y S Q L$}

Menurut Dani Eko Hendrianto(2014) MySQL adalah multiuser database yang menggunakan bahasa StructuredQueryLanguage(SQL). MySQL dalam operasi clientserver melibatkan serverdaemon MySQL disisi server dan berbagai macam program serta library yang berjalan di sisi client. MySQL mampu menangani data yang cukup besar. Perusahaan yang mengembangkan MySQL yaitu TEX, mengaku mampu menyimpan data lebih dari 40 database, 10.000 tabel, dan sekitar 7.000 .000 baris totalnya kurang lebih 100 Gigabyte data.

\section{METODOLOGI PENELITIAN}

Untuk menyusun tugas akhir ini, dilakukan metode penelitian dalam memperoleh data-data yang dibutuhkan sehingga penyusunan penelitian ini dapat diselesaikan dengan baik dan sistematis.

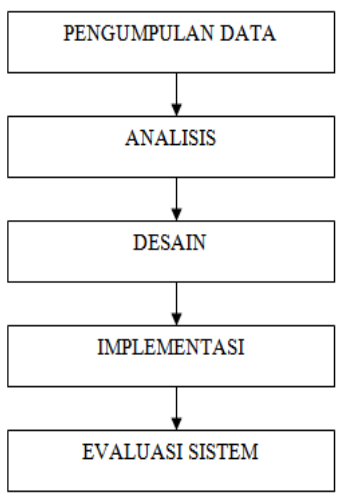

Gambar 1. Kerangka Kerja

\section{A. Obyek Penelitian}

Objek penelitian merupakan permasalahan yang diteliti. Objek dari penelitian ini adalah bagaimana membangun sebuah aplikasi pelayanan jasa laundry pada Pelangi laundry Kisaran.

\section{B. Pengumpulan Data}

Metode yang digunakan dalam proses pengumpulan data sebagai bahan pembuatan sistem adalah :

1. Studi Lapangan (field research)

Studi Lapangan dilakukan dengan cara :

a. Observasi Lapangan Langsung

Dengan menggunakan metode observasi lapangan langsung, penulis melakukan pengamatan secara langsung mengenai pelayanan jasa laundry yang ada di tempat penulis melakukan penelitian dan mencatat semua informasi yang ada yang mendukung penyusunan tugas akhiri ini.

b. Wawancara (interview)

Penulis mengadakan tanya jawab secara langsung baik secara formal maupun non formal dengan pihak-pihak yang terkait dalam permasalahan yang akan dibahas dalam penulisan penelitian, yaitu dengan menggunakan metode penulisan tangan atau handwriting.

\section{Studi Kepustakaan (library research)}

Yaitu dengan mendatangi perpustakaan dan mencari buku-buku literatur yang sesuai dengan masalah yang diangkat, dan informasi yang didapat digunakan untuk memecahkan masalah yang berkaitan dengan prosedur. Data yang diperoleh melalui studi kepustakaan adalah 
sumber informasi yang telah ditemukan oleh para ahli yang kompeten dibidangnya masing-masing sehingga relevan dengan pembahasan yang sedang diteliti, dalam melakukan studi kepustakaan ini penulis berusaha mengumpulkan data sebagai berikut :

a. Mempelajari konsep dan teori dari berbagai sumber yang berhubungan dan mendukung pada masalah yang sedang diteliti.

b. Mempelajari materi kuliah dan bahan tertulis lainnya.

\section{Metode Analisis Data}

Setelah melakukan pengumpulan data tahap berikutnya adalah menganalisis data yang berhasil dikumpulkan untuk mencapai suatu kesimpulan. Adapun analisis data yang dilakukan penulis adalah Metode Analisis Deskriptif.

Metode deskriptif adalah suatu metode dalam meneliti status sekelompok manusia, suatu obyek, suatu set kondisi, suatu sistem pemikiran, ataupun suatu kelas peristiwa pada masa sekarang. Metode penelitian deskriptif bertujuan untuk membuat deskripsi, gambaran atau lukisan secara sistematis, faktual dan akurat mengenai fakta-fakta serta hubungan antar masalah dan kondisi yang diselidiki dengan cara mengumpulkan data, mengolah, menganalisis, dan mengimplementasikan data ke dalam aplikasi. Seperti memberikan informasi yang up-to-date dari Pelangi Laundry tentang jasa laundry yang ditawarkan kepada pelanggan, memberikan pelayanan antar-jemput laundry yang cepat dan terpercaya kepada pelanggan, memudahkan proses pembuatan laporan pendapatan dengan cepat, tepat dan akurat, memberikan pelayanan yang profesional kepada pelanggan dan meminimalisir kesalahankesalahan yang mungkin terjadi sehingga nantinya aplikasi yang dihasilkan dapat memberikan manfaat sebesar-besarnya kepada penggunanya.

\section{A. Analisis Masalah}

\section{ANALISA DAN PERANCANGAN}

Dalam melakukan pembangunan aplikasi ini terdapat beberapa masalah dan faktor-faktor penting yang perlu diperhatikan. Faktor-faktor yang akan dianalisis tersebut, yaitu mengenai permasalahan bagaimana seorang Pelanggan memperoleh informasi yang up-to-date dari Pelangi laundry, memperoleh pelayanan jasa antar-jemput Laundry dan memperoleh pelayanan proses transaksi yang cepat, tepat dan akurat. Hasil analisis ini akan dijadikan sebagian acuan dalam pembangunan aplikasi pelayanan jasa Laundry pada Pelangi Laundry Kisaran berbasis web.

\section{B. Perancangan UML}

Untuk lebih memperjelas tentang gambaran sistem maka penulis membuat UML (Unified Modeling Language ) dengan beberapa tipe yaitu Use case, Class diagram, sequence diagram dan Activity diagram.

\section{Use Case Diagram}

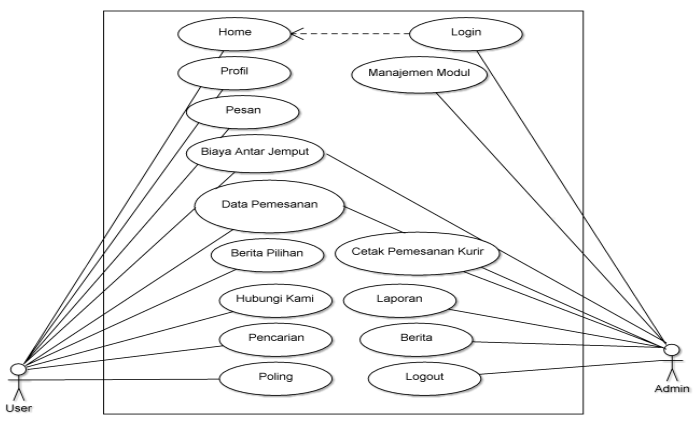

Gambar 2 Use Case Diagram

Pada Gambar 2 adalah rancangan dari diagram Use Case manajemen, dimana diagram use case akan menjelaskan mengenai admin yang berinteraksi dengan sistem database server. Perancangan diagram ini menggambarkan suatu fungsionalitas sebuah sistem yang ditekankan pada apa yang diperbuat oleh admin dalam mengolah data-data yang diperlukan oleh sistem.

2. Activity Diagram Pada User

Activity Diagram pada User menjelaskan semua proses yang akan dilakukan oleh pelanggan mulai dari memilih halaman Home, Profil, Pesan, Data Pemesanan dan Biaya Antar Jemput.

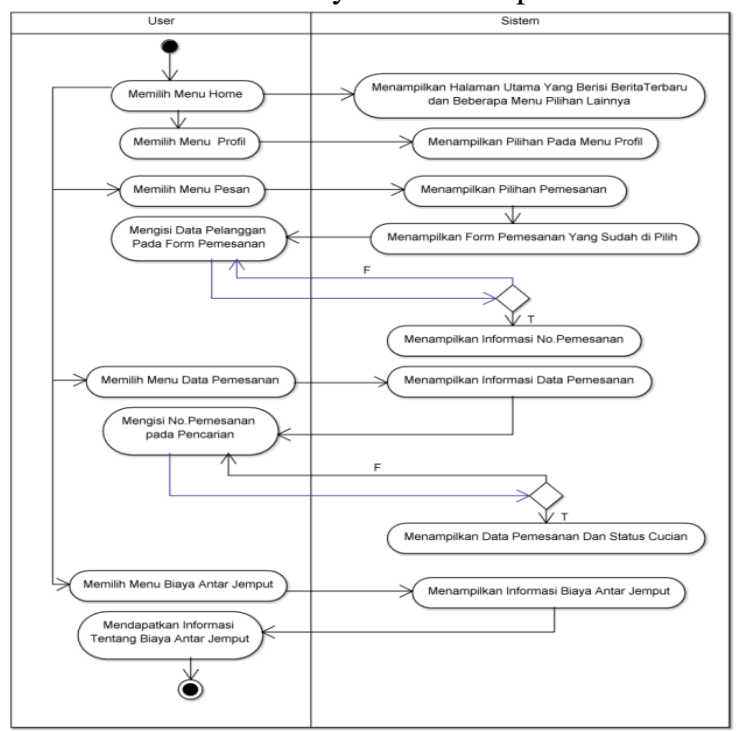

Gambar 3 Activity Diagram Pada User

3. Activity Diagram Pada Admin

Activity Diagram pada Admin menjelaskan semua proses yang akan dilakukan oleh Admin mulai dari memilih halaman Home, Data Pemesanan, Cetak Pemesanan Kurir, Laporan, Berita dan Biaya Antar Jemput. Admin juga dapat mengolah semua data yang ada sehingga pelanggan akan menerima informasi-informasi terbaru. 


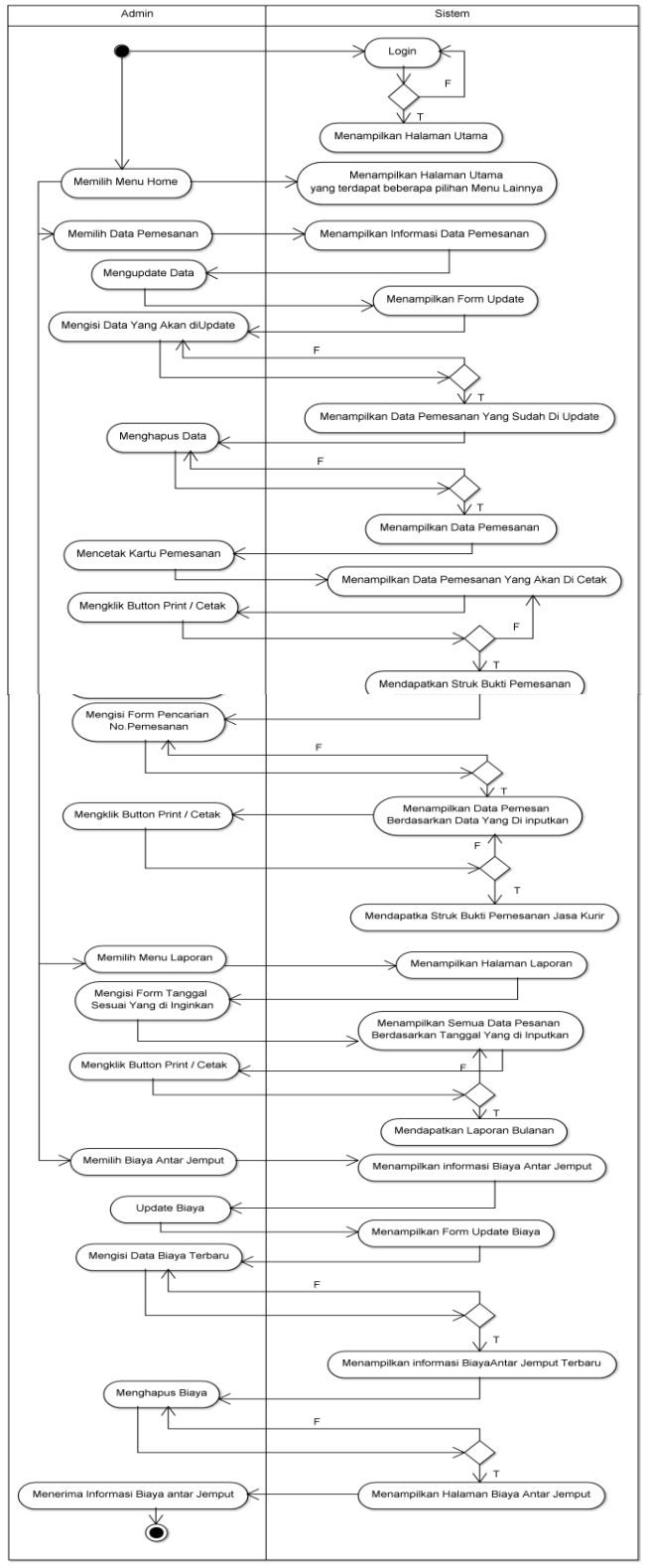

Gambar 4 Activity Diagram Pada Admin

4. Class Diagram.

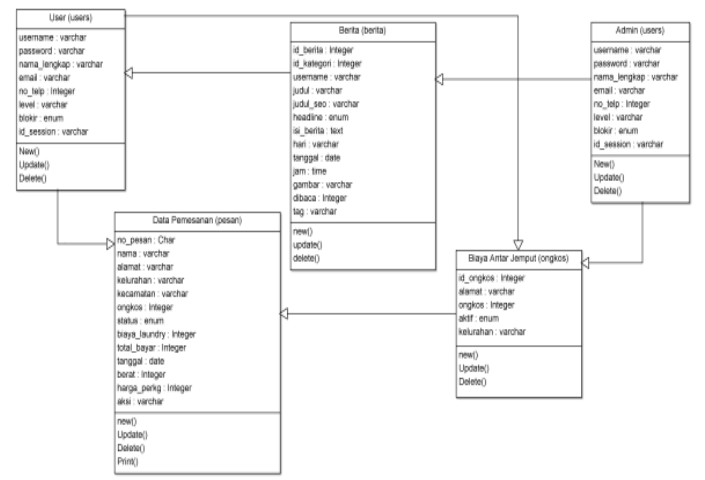

Gambar 5 Class Diagram
5. Sequence Diagram Pada Admin

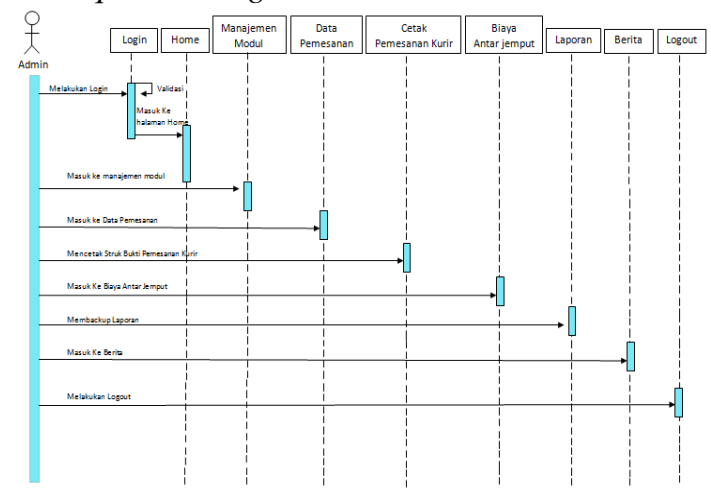

Gambar 6 Squence Diagram Pada Admin

Pada sequence diagram admin ini, menerangkan serangkaian hubungan yang terjadi antara aktor dan objek-objek serta kelas objek pada saat admin akan melalukan kegiatan. Dalam diagram ini aktor yang terlibat adalah admin yang menggunakan komputer dan alat pencetak. Sedangkan objek yang berinteraksi dengan aktor tersebut adalah Aplikasi jasa laundry.

6. Sequence Diagram Pada User

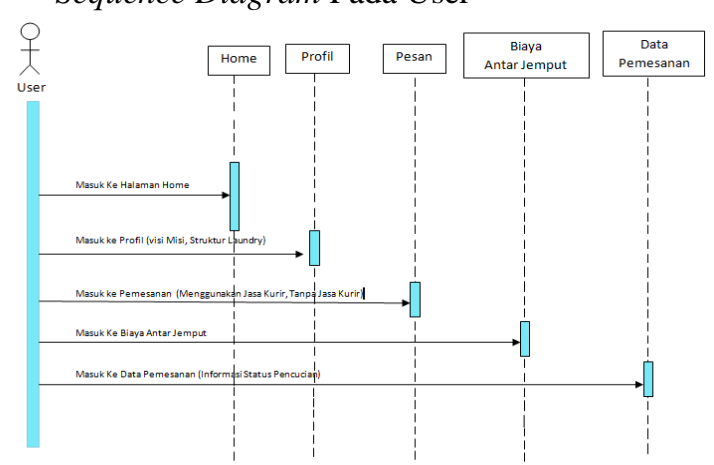

Gambar 7 Squence Diagram Pada User

Pada sequence diagram User ini, menerangkan serangkaian hubungan yang terjadi antara aktor dan objek-objek serta kelas objek pada saat User akan melalukan kegiatan. Dalam diagram ini aktor yang terlibat adalah user yang menggunakan komputer atau telepon seluler. Sedangkan objek yang berinteraksi dengan aktor tersebut adalah Aplikasi jasa laundry.

7. Tampilan Login Admin

Tampilan halaman login merupakan tampilan awal sebelum masuk ke dalam menu admin. Setelah sukses proses login maka akan menuju ketampilan menu utama admin. 


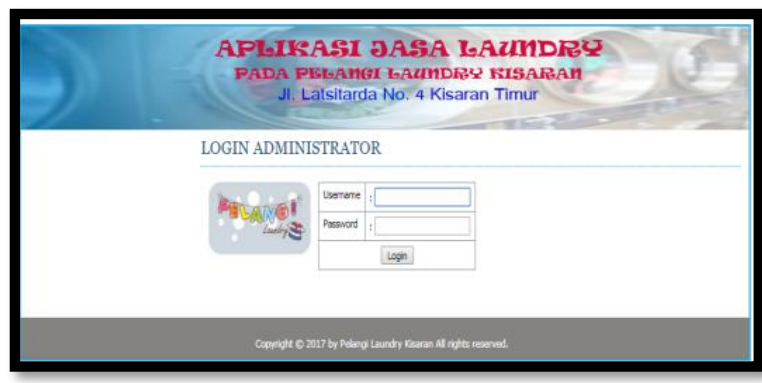

Gambar 8 Tampilan Login Admin

8. Tampilan Halaman Home Pada Admin Tampilan halaman admin merupakan tampilan admin untuk melakukan penginputan informasi terbaru.

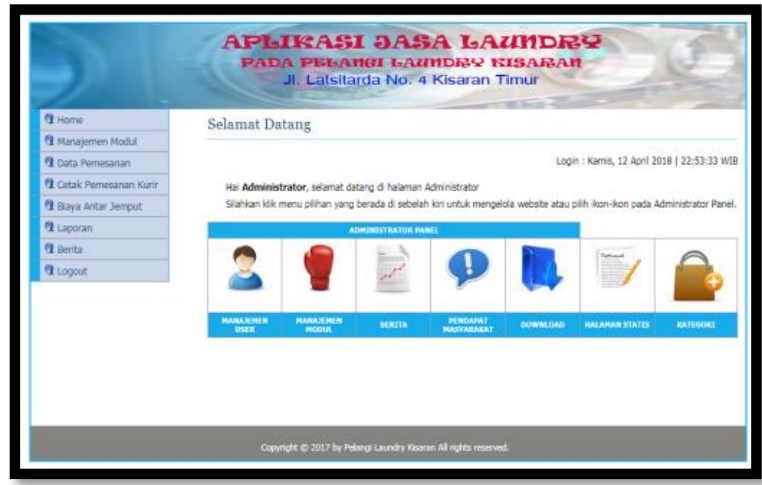

Gambar 9 Halaman Admin

9. Tampilan pemesanan yang telah di terima oleh admin

Tampilan Data pemesanan merupakan tampilan yang berisi tentang data-data pemesanan yang akan di kelola oleh admin sehingga proses transaksi dengan mudah dilaksanakan.

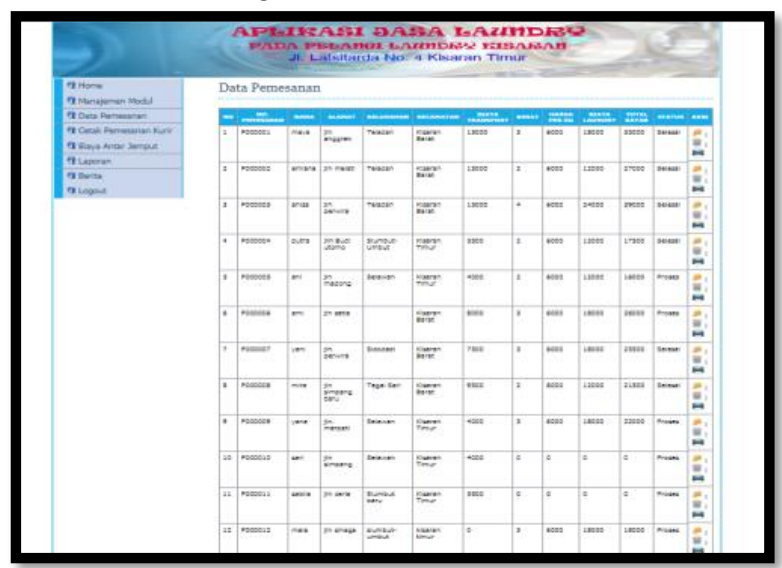

Gambar 10 Tampilan pemesanan yang telah di terima oleh admin

10. Tampilan Cetak Pemesanan Kurir

Tampilan cetak pemesanan kurir merupakan tampilan yang digunakan untuk mencetak bukti pemesanan jasa kurir yang di pesan oleh user, bukti pemesanan jasa kurir ini hanya bisa di cetak oleh admin.

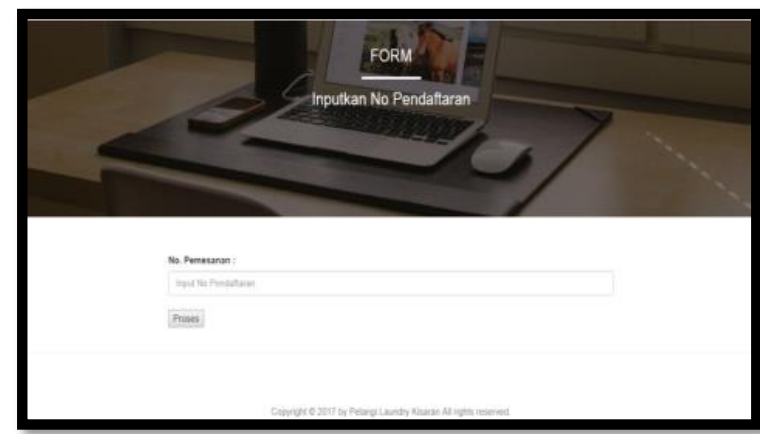

Gambar 11 Tampilan Cetak Pemesanan Kurir

11. Tampilan Home pada User

Tampilan Home merupakan tampilan yang berisi tentang informasi berita terbaru yang up-to-date yang dapat dilihat oleh user.

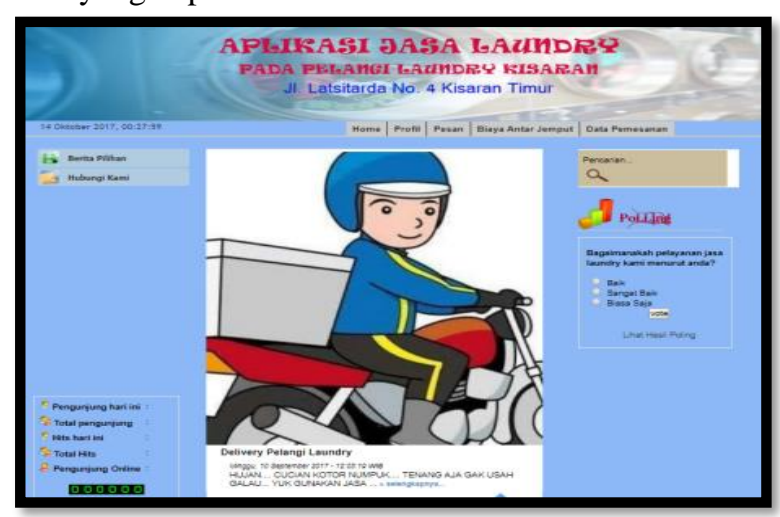

Gambar 12 Tampilan Home pada User

12. Tampilan Pemesanan Jasa kurir

Tampilan pemesanan merupakan tampilan yang berisi informasi pemesanan jasa kurir yang di isi oleh user.

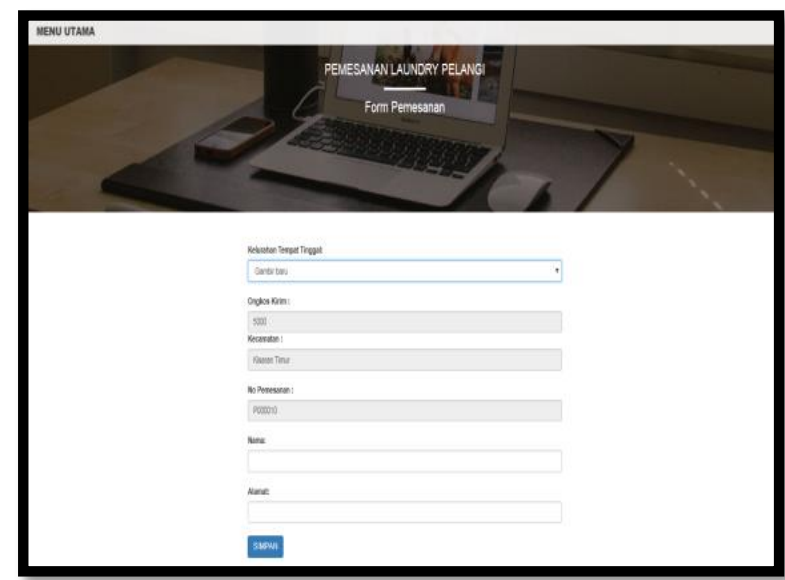

Gambar 13 Tampilan Pemesanan Jasa Kurir

\section{PENUTUP}

A. Kesimpulan

Dari hasil pembahasan pada bab-bab yang telah diuraikan sebelumnya, maka penulis mengambil kesimpulan sebagai berikut :

1. Aplikasi ini memberikan solusi alternative untuk memudahkan pelanggan dalam memperoleh 
informasi yang up-to-date dari Pelangi Laundry tentang jasa laundry yang ditawarkan.

2. Aplikasi ini berguna untuk memudahkan pelanggan dalam memperoleh pelayanan jasa antar-jemput Laundry dengan cepat dan terpercaya, serta memudahkan pegawai dalam pembuatan laporan pendapatan pada pelangi Laundry

3. Untuk dapat merancang Aplikasi pelayanan jasa Laundry pada pelangi laundry kisaran berbasis web ini diperlukan program notepad++, XAMPP, PHPMyadmin, Database MySQL dan aplikasi browser seperti google chrome dan internet explorer.

\section{B. Saran}

Saran yang dapat diberikan oleh Penulis untuk pengembangan perancangan aplikasi ini adalah

1. Sistem Informasi yang telah dibangun ini perlu dilakukan penelitian dan pengembangan lebih lanjut lagi dengan menggunakan imajinasi yang tinggi supaya tercipta aplikasi pelayanan jasa laundry yang lebih bagus dengan menggunakan aplikasi lainnya.

2. Antarmuka dapat dibuat lebih menarik lagi untuk ke depannya sehingga dapat membuat sistem ini menjadi user friendly.

3. Mengevaluasi secara lebih lanjut lagi untuk menyempurnakan aplikasi terutama terhadap keamanan sistem.

\section{DAFTAR PUSTAKA}

[1] Bunafit Nugroho, 2013. Dasar Pemrograman Web PHP MySQL. Yogyakarta: Penerbit Gava Media

[2] Dani Eko Hendrianto, 2014. "Pembuatan Sistem Informasi Perpustakaan Berbasis Website Pada Sekolah Menengah Pertama Negeri 1 Donorojo Kabupaten Pacitan”. IJNS - Indonesian Journal on Networking and Security, Volume 3 No 4. ISSN: 2302-5700 (Print) 2354-6654 (Online).

[3] Hasan Abdurahman dan Asep Ririh Riswaya, 2014. "Aplikasi Pinjaman Pembayaran Secara Kredit pada Bank Yudha Bhakti”. Jurnal Computech \& Bisnis, Volume 8 No 2. ISSN: 2442-4943.

[4] Muhammad Syawal Ainul Yaqin, 2016. "Analisis Perancangan Aplikasi Layanan Laundry Berbasis Visual Basic 2010 pada Gajayana Laundry”. Seminar Nasional Teknologi Informasi dan Multimedia 2016. ISSN: 2302-3805

[5] Refika Khoirunnissa dkk, 2016. "Pembuatan Aplikasi Web Manajemen Laundry dan Integrasi Data Dengan Web Service”. Jurnal Teknologi dan Sistem Komputer, Volume 4 No 1. e-ISSN: 2338 0403. 